\title{
JEECAR Editorial Notes
}

\section{The U.S. Influence on Eurasia and Research Opportunity}

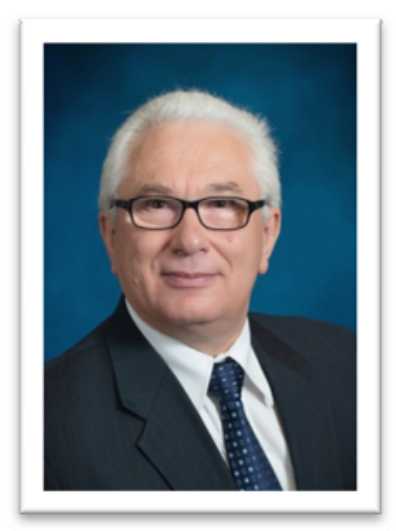

Spanning through various economic and political aspects of social science, the Journal JEECAR covers key issues concerning today's situation in Eurasia. While seeking to provide a publishing opportunity to academics, researchers and expert-practitioners, JEECAR is a unique voice for the region covered. In our fourth year of service to the academic community, as an ongoing publication, we hope to reach out to an even wider audience and to continue sharing our academic discoveries internationally. Current world politics support our desire.

Especially, since the election of the new American President, the Washington position has became even more uncertain with regard to U.S. political activities in Eurasia. NATO is moving toward the Russian border but in response, Russia, as a reaction to the US and EU sanctions, becomes more and more aggressive toward its European neighbors. In today's reality, President Putin is completely isolated by Western leaders and President Trump is cornered by the U.S. politicians and media.

The Romans said that if you want peace, prepare for war. United States' desire to store large amounts of ammunition in the Baltic States and several Central European countries in an attempt to ease their fears arising from Russia's invasion in Donbas region of Ukraine and occupation of Crimea, has invited a strong reaction from Moscow. President Vladimir Putin declared that Russia would add over 40 nuclear intercontinental ballistic rockets capable of overwhelming any NATO missile defense system. Evermore, Estonia, as well as Lithuania, Latvia, Bulgaria, Romania, and Poland as the new NATO members, have agreed to host heavy weapons. In response, Russia announced that it is tripling the size of its Response Force to 40,000 troops. As proof, this summer Russia conducted its biggest military drill in Belarus, which created a severe tension in Poland, Ukraine, and Baltic states. What is arising between NATO and Russia is threatening. However, current political tension in Washington, DC, and constant ongoing investigations of the President Trump team does not help in establishing open-minded and trustworthy cooperation between the US and Russia that would allow releasing the Eastern European tension.

Russian presidential elections of 2019 are on the horizon, and Putin's hard-line stand is backed by the Russian public's growing hatred toward the U.S. and Europe. The latest opinion survey taken in September showed that $63 \%$ of those polled regarded the U.S. as a threat, compared with just 51 percent in a 2016 poll. US-Russia trade is down $36 \%$ compared to 2015 , which threatens to shrink the Russian economy by additional $4 \%$ this year, in addition to 3\% GDP lost in 2015, because of the Western sanctions over Ukraine. Also, falling crude oil prices add to Russian economic recession. Putin holds a robust popular approval rate of around 82 percent and a list of a dozen of somewhat weak potential Presidential candidates is not a concern to his cabinet. Nevertheless, the U.S. and Russia should strive to commit to lessening Cold War tensions, respect Ukrainian territorial integrity, and avoid the threat of using force against others.

As we see, the current American and European domestic politics and their reflection on Eurasia provide enormous research opportunities in field of economics and international affairs.

Finally, I would like to take this opportunity to thank the entire JEECAR Editorial Board for their time, energy, and enthusiasm throughout the 2017 year. This issue would not have been possible without the many hours they have all put into it. I would like to thank especially Deputy Editor Dr. Charlotte Davis for the outstanding work on editing of each article we publish. Thanks also go to all our Copy Editors and Reviewers who have so kindly offered their time and professional support to this issue. Last, but certainly by no means least, sincere thanks go to Dr. Julian Schuster, Chairman of Advisory Board and Provost and Executive Vice President of Webster University in St. Louis, MO for his guidance and support.

On the behalf of the JEECAR Editorial Board, I would like to congratulate Chu V. Nguyen, Phan Dinh Khoi, and Marvin J. Williams on receiving the "BEST PAPER" award for the article "The transmission mechanism of Russian Central Bank's countercyclical monetary policy since 2011: Evidence from the Interest Rate Pass-Through” published in this Vol. 4 No. 2 (2017) JEECAR issue.

Nikolay Megits, Ph.D.

JEECAR Editor-in-Chief 